\title{
Eating habits and antifat attitudes among adolescent: West Serbian experience
}

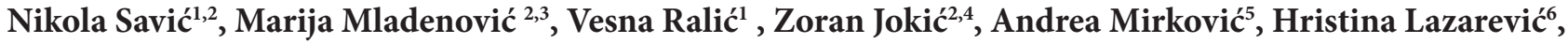 \\ Slobodanka Bogdanović Vasić 7 Jasna Petrovićc ${ }^{2,3}$
}

\author{
1. Medical School "Dr Miša Pantic" Valjevo, \\ 2. Singidunum University, Faculty of Health and Business Studies, Department of Nursing, Valjevo, Serbia, \\ 3. Valjevo General Hospital, \\ 4. Polyclinic Jokić Valjevo, \\ 5. Eye ambulance "Etiko" Kragujevac, \\ 6. Health Institution "Zdravlje Lek" Kragujevac, \\ 7. Academy of Vocational Studies Šabac.
}

Corresponding author: MSc Nikola Savić, Master teacher Singidunum University, Faculty of Health and Business Studies, Department of Nursing, Valjevo, Serbia

E mail - nikolasavicvzs@gmail.com
Proces prihvatanja/Article history:

Primljeno/Received 07.04.2021

Revidirano/Received in revised form 19.04.2021.

Prihvaćeno/Accepted 23.04.2021.

\section{NAVIKE U ISHRANI I STAVOVI ADOLES- CENATA KOD MASNE HRANE - ISKUSTVO ZAPADNE SRBIJE \\ SAŽETAK}

Uvod Ishrana ima veliki uticaj na zdravstveni potencijal mladih. Veoma je važno pravovremeno analizirati aspekte ishrane adolescenata, kako bi se identifikovali potencijalni zdravstveni rizici. Cilj: Cilj studije je ispitati navike $\mathrm{u}$ ishrani i stavove adolescenata prema gojaznosti.

Metode: U istraživanju je učestvovalo 370 učenika Medicinske škole "Dr Miša Pantić" Valjevo, Srbija. Istraživanje je sprovedeno kao studija preseka, prvi deo upitnika odnosio se na demografske karakteristike, drugi deo instrumenta ispituje prehrambene navike, treći deo upitnika se odnosi na aspekte gojaznosti, koristeći AFA skalu gojaznosti. Performanse skale testirane su Cron Bachovim alfa testom $(\alpha=.78)$.

Rezultati: Rezultati su pokazali da se većina ispitanika hrani pravilno i nema preskakanja obroka. Zabrinjavajuće je da je potrošnja slatkiša i gaziranih pića velika. Devojke su u velikom broju izjavile da ne vole gojazne ljude. Većina razlika između zdravih i nezdravih navika dolazi iz životnog okruženja i nivoa obrazovanja roditelja.

Zaključci: Godine tranzicije su donele nepravilne prehrambene navike kod populacije adolescenata, potrebno je više zdravstvenog obrazovanja da bi se očuvalo zdravlje mladih.

Ključne reči: adolescencija, zdrava ishrana, stavovi adolescenata o gojaznosti.

\begin{abstract}
Introduction Nutrition has a great impact on the health potential of young people. It is very important to analyze aspects of adolescent nutrition in a timely manner, in order to identify potential health risks.

Objectives The aim of the study is to examine adolescents' eating habits and attitudes toward obesity.

Methods 370 students from the Valjevo Medical School, Western Serbia, participated in the study. The survey was designed as a cross-sectional study, using the questionnaire whose first part was related to demographic characteristics of participants, the second part of the instrument examined eating habits, while the third part dealt with obesity, using the AFA obesity scale. Scale performance was tested by Cronbach's alpha test $(\alpha=.78)$.

Results The results showed that the majority of the subjects were eating properly and without skipping meals. It was worrying that the consumption of sweets and sodas was high. Females stated in large numbers that they disliked obese people. Most of the differences between healthy and unhealthy habits come from the living environment and parental level of education.

Conclusions The transition years have brought some irregular eating habits in the adolescent population, more education is needed to maintain a healthy life.
\end{abstract}

Key words: Adolescence, healthy eating, adolescents' attitudes about obesity. 


\section{INTRODUCTION}

South-East Europe, particularly West Balcan is going through a huge transition. Significant political and social changes have occurred during the last decades and rapid socio-cultural changes put adolescents at risk for developing various health problems. Adolescence is a complicated developmental period, with both psychological and physiological changes. Also, this is a vulnerable stage of life in terms of nutrition, with a higher prevalence of food-related disorders owing to lifestyle and eating habits. The nutrient needs of adolescents are higher than those of children and adults. Also, parenteral control regarding eating habits reduces in this period of life. In addition, the composition of the diet is not adequate, i.e. too much protein, fats, sugar are being used, while there is an insufficient intake of vegetable, fruit and milk products in adolescents diet. Skipping breakfast and taking snacks are highly prevalent among adolescents. Consuming unhealthy foods throughout the day is common. Owing to their school duties, adolescents are more likely to eat away from home on a daily basis. Food-related disorders, including eating disorders, under nutrition, overweight and obesity are very common in this population. Although contemporary media propagate thinness and slenderness, obesity is a serious health concern not only for adults but for children and adolescents as well. The rising prevalence of obesity and metabolic syndrome among adolescents put the whole population at great risk of developing non-communicable diseases, which have been of growing concern in many counties in transition. According to the World Health Organization, the major causes that lead to obesity during childhood or adolescence are increased energy intake, decreased physical activity, sedentary lifestyle, changing modes of transportation, increasing urbanization and other societal reasons [1]. Due to media promoting fit and thin appearance, there are a lot of antifat attitudes and stereotypes toward obese people among children, adolescents and adults, by attributing to them more negative and fewer positive traits than to normal-weight people. Studies examining eating habits of adolescents, as well as antifat attitudes among them, are very limited in Serbia [1-3]. The aim of the study was to examine attitudes toward overweight and obesity among medical school students, to determine differences in attitudes toward overweight and obesity according to different levels of socio-demographic data (gender, parenteral edu- cation and living area), as well as to investigate eating habits among medical school students.

\section{METHODS}

The research was conducted in the form of a cross-sectional study. In total,370 students from the Medical School "Dr Misa Pantic" in Valjevo, Serbia participated in the study. The sample consisted of students from all grades and from the following educational profiles: Nurse, Pediatric Nurse, Physiotherapy Technician, Laboratory Technician and Pharmaceutical Technician.

The criterion for inclusion in the research was provided written consent of the parents and personal consent of the student to participate in the study. The exclusion criteria were the lack of written consent to participate in the research, as well as the lack of readiness of students to answer all the questions in the questionnaire. The research instrument was a questionnaire, specially designed for the purposes of this research. The time required to complete the questionnaire was 45 minutes.

The first part of the questionnaire contained questions related to the demographic characteristics of the respondents, namely gender, age and family aspects. The second part of the research instrument examined student's eating habits. The third part of the questionnaire examined student's attitudes towards obesity. In this part of the study, the Antifat Attitudes Questionnaire (AFA) and Obesity Attitude Scale were used. The efficacy of the scale has been repeatedly demonstrated in the available literature and tested by the Cronbach's alpha test $(\alpha=.78)$. Antifat Attitudes Questionnaire consisted of 14 claims, with a modified three-level Likert scale (1 for dissent, 2 neutral, 3 for agree).

The research was approved by the competent authorities of the Medical School "Dr Misa Pantic" in Valjevo. Informed consent was obtained from all individual respondents included in the study. The survey was conducted from September to October of 2018. The research sites were the school premises and classrooms. The sample of students was intentional. Prior to the start of the study, students and parents were provided with the necessary information regarding the study itself, both verbally and in writing. Students were given instructions regarding how to complete the questionnaire correctly.

Questionnaire distribution and data collection were conducted by the researchers personally. Weight and height were measured according to a standardized 
protocol. Body weight $(\mathrm{kg})$ and height $(\mathrm{cm})$ were measured with an electronic scale and stadiometer. Body mass index (BMI) $(\mathrm{kg} / \mathrm{m} 2)$ was calculated as body weight $(\mathrm{kg})$ divided by the height squared (m2). Data processing involves descriptive statistics methods. The results are presented graphically and in tabular form.

\section{RESULTS}

The largest number of respondents was female, male respondents made up the sample of $42 \%$. Respondents indicated that they lived mostly in urban areas (63\%), less in a rural environment (37\%). The majority of respondents lived with both parents (89\%); the majority of parents have only completed secondary school (Supplementary Table 1).
(10\%) for the lunch. Among the respondents, the majority of students receive information on healthy nutrition via the Internet (36\%), a total of 33\% in discussions with parents, with professors $17 \%$ and only $14 \%$ from health professionals. The largest number of students is involved in sports $81 \%$, only $19 \%$ was not engaged in the sports activity. A tabular view of adolescent eating habits is given in Table 2 .

The majority of the students had a normal body mass index (71\%), those with overweight and obesity were represented by $23 \%$, and underweight by only $6 \%$. When it comes to the attitudes of the respondents regarding obesity, in most cases female students had a more negative attitude. Male students expressed fewer negative attitudes toward obesity and obese people. In a minority of cases, discriminatory behavior

Table 1. Socio-demographic characteristics of all participants

\begin{tabular}{ll}
\hline Distribution of respondents & Research results: \\
\hline Gender: & $\begin{array}{l}\text { female } 58 \%, \\
\text { male } 42 \% .\end{array}$ \\
\hline Educational level: & all students attend high school (100\%). \\
\hline Place of living: & $\begin{array}{l}\text { urban } 63 \%, \\
\text { rural } 37 \%\end{array}$ \\
\hline Family structure: & $\begin{array}{l}\text { both parents } 89 \%, \\
\text { respondents living with only mother } 11 \% .\end{array}$ \\
\hline Mother's education: & elementary school 12\% \\
& $\begin{array}{l}\text { high school } 72 \% \\
\text { university education } 16 \%\end{array}$ \\
\hline Father's education: & $\begin{array}{l}\text { elementary school } 16 \% \\
\text { high school 70\% } \\
\text { university education } 14 \%\end{array}$ \\
\hline
\end{tabular}

In the examined sample, the highest number of students had three meals (47\%), four meals had $22 \%$, while the smallest portion of students had less than three meals (4\%). Most students (79\%) stated that their meals were diverse. In the study's sample, the largest number of students consumed breakfast between 6 and 9 AM (67\%). The largest number of students had dinner between 6 PM and 8 PM (74\%). Among them, the majority consumed sweets and snacks several times during the day (44\%), once a day $23 \%, 2-3$ times a week $19 \%$, never $14 \%$. Among the respondents, the majority were students who consumed carbonated, energy and alcoholic beverages $(82 \%)$.

Most of the respondents consumed food from the bakery (69\%), minority brought food from home and support for stereotypes and prejudices regarding the obese population were manifested.

The results are moderately negative when it comes to the self-control and self-esteem of obese people. Fear of gaining weight is more pronounced in female subjects in the observed sample (Supplementary Table 3).

\section{DISCUSSION}

Overweight is seen as a problem not only in wealthy countries, but in low and middle-income countries, and it is rapidly growing [4]. The proportion of overweight children aged between 5-19 rose from 10,3\% in 2000 to $18,4 \%$ in 2016 [5]. This increase was driven by rising intake of calories, a shift from traditional to modern diets, urbanization and decreasing levels of physical activity. Among adolescents, the preva- 
Table 2. Adolescent eating habits

\begin{tabular}{|c|c|c|c|c|c|c|}
\hline \multirow[b]{2}{*}{ Predictors: } & \multicolumn{2}{|c|}{ Gender } & \multicolumn{2}{|c|}{ Place of living } & \multicolumn{2}{|c|}{ Education of parents } \\
\hline & females & male & $\begin{array}{c}\text { urban } \\
\text { environment }\end{array}$ & $\begin{array}{c}\text { rural } \\
\text { environment }\end{array}$ & $\begin{array}{c}\text { Primary and } \\
\text { secondary } \\
\text { school }\end{array}$ & $\begin{array}{l}\text { University } \\
\text { education }\end{array}$ \\
\hline \multicolumn{7}{|c|}{ Distribution of respondents by number of meals per day } \\
\hline three & $29 \%$ & $18 \%$ & $37 \%$ & $10 \%$ & $23 \%$ & $24 \%$ \\
\hline four & $5 \%$ & $17 \%$ & $10 \%$ & $12 \%$ & $6 \%$ & $6 \%$ \\
\hline five & $4 \%$ & $15 \%$ & $9 \%$ & $10 \%$ & $17 \%$ & $2 \%$ \\
\hline less than three & $3 \%$ & $1 \%$ & $3 \%$ & $2 \%$ & $3 \%$ & $2 \%$ \\
\hline more than five & $2 \%$ & $6 \%$ & $1 \%$ & $6 \%$ & $4 \%$ & $1 \%$ \\
\hline \multicolumn{7}{|c|}{ Distribution of respondents according to time consuming breakfast } \\
\hline 6 to 9 AM & $37 \%$ & $30 \%$ & $29 \%$ & $38 \%$ & $27 \%$ & $40 \%$ \\
\hline 9 to $11 \mathrm{AM}$ & $10 \%$ & $23 \%$ & $12 \%$ & $21 \%$ & $17 \%$ & $16 \%$ \\
\hline \multicolumn{7}{|c|}{ Distribution of respondents by time consuming dinner } \\
\hline $5 \mathrm{PM}$ to $8 \mathrm{PM}$ & $42 \%$ & $32 \%$ & $33 \%$ & $41 \%$ & $31 \%$ & $43 \%$ \\
\hline After 8 PM & $7 \%$ & $19 \%$ & $14 \%$ & $12 \%$ & $18 \%$ & $8 \%$ \\
\hline \multicolumn{7}{|c|}{ Distribution of respondents by consumption of sweets and snacks } \\
\hline $\begin{array}{l}\text { multiple times } \\
\text { throughout the } \\
\text { day }\end{array}$ & $19 \%$ & $25 \%$ & $27 \%$ & $17 \%$ & $22 \%$ & $22 \%$ \\
\hline once a day & $4 \%$ & $19 \%$ & $19 \%$ & $4 \%$ & $13 \%$ & $10 \%$ \\
\hline 2-3 times a week & $15 \%$ & $4 \%$ & $12 \%$ & $7 \%$ & $8 \%$ & $11 \%$ \\
\hline very often / never & $11 \%$ & $3 \%$ & $9 \%$ & $4 \%$ & $5 \%$ & $8 \%$ \\
\hline \multicolumn{7}{|c|}{ Distribution of respondents according to how they gain knowledge about healthy eating } \\
\hline From my parents & $19 \%$ & $14 \%$ & $12 \%$ & $21 \%$ & $12 \%$ & $21 \%$ \\
\hline $\begin{array}{l}\text { Internet and } \\
\text { television }\end{array}$ & $14 \%$ & $22 \%$ & $20 \%$ & $16 \%$ & $19 \%$ & $17 \%$ \\
\hline $\begin{array}{l}\text { Healthcare } \\
\text { professionals }\end{array}$ & $10 \%$ & $4 \%$ & $8 \%$ & $6 \%$ & $3 \%$ & $11 \%$ \\
\hline Professors & $11 \%$ & $6 \%$ & $13 \%$ & $4 \%$ & $5 \%$ & $12 \%$ \\
\hline
\end{tabular}

\section{Student body mass index}

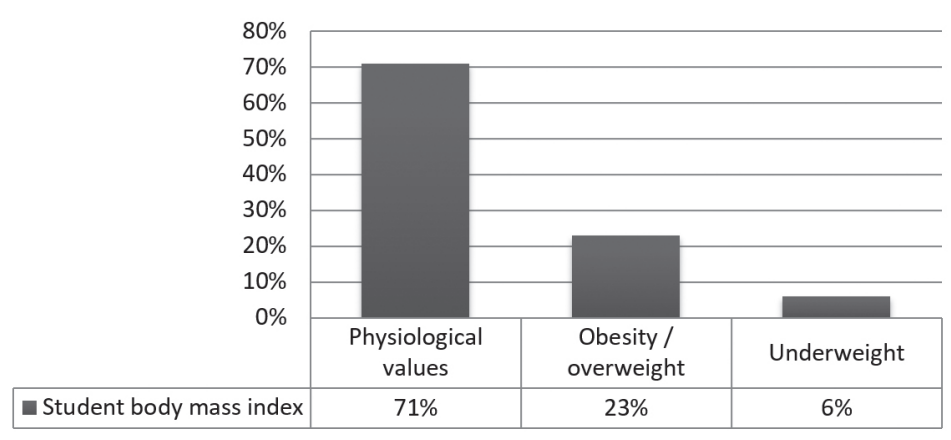

Chart 1 - Distribution of students by Body mass index (BMI) 
Table 3. Attitude towards obesity (AFA)

\begin{tabular}{|c|c|c|c|c|c|c|}
\hline GENDER & \multicolumn{3}{|c|}{ FEMALES } & \multicolumn{3}{|c|}{ MALE } \\
\hline $\begin{array}{l}\text { Attitude towards obesity and } \\
\text { obesity (AFA) }\end{array}$ & $\begin{array}{l}\text { I do not } \\
\text { agree }\end{array}$ & $\begin{array}{l}\text { I have no } \\
\text { opinion }\end{array}$ & I agree & $\begin{array}{l}\text { I do not } \\
\text { agree }\end{array}$ & $\begin{array}{l}\text { I have no } \\
\text { opinion }\end{array}$ & I agree \\
\hline I really don't like fat people much. & $94 \%$ & $5 \%$ & $1 \%$ & $90 \%$ & $3 \%$ & $7 \%$ \\
\hline $\begin{array}{l}\text { I don't have many friends that are } \\
\text { fat. }\end{array}$ & $24 \%$ & $0 \%$ & $76 \%$ & $21 \%$ & $9 \%$ & $70 \%$ \\
\hline $\begin{array}{l}\text { I tend to think that people } \\
\text { who are overweight are a little } \\
\text { untrustworthy. }\end{array}$ & $5 \%$ & $7 \%$ & $88 \%$ & $2 \%$ & $8 \%$ & $90 \%$ \\
\hline $\begin{array}{l}\text { Although some fat people are } \\
\text { surely smart, in general, I think } \\
\text { they tend not to be quite as bright } \\
\text { as normal weight people. }\end{array}$ & $98 \%$ & $1 \%$ & $1 \%$ & $81 \%$ & $9 \%$ & $10 \%$ \\
\hline $\begin{array}{l}\text { I have a hard time taking fat } \\
\text { people too seriously. }\end{array}$ & $94 \%$ & $6 \%$ & $0 \%$ & $92 \%$ & $4 \%$ & $4 \%$ \\
\hline $\begin{array}{l}\text { Fat people make me somewhat } \\
\text { uncomfortable. }\end{array}$ & $90 \%$ & $6 \%$ & $4 \%$ & $82 \%$ & $8 \%$ & $10 \%$ \\
\hline $\begin{array}{l}\text { If I were an employer looking to } \\
\text { hire, i might avoid hiring a fat } \\
\text { person. }\end{array}$ & $73 \%$ & $2 \%$ & $25 \%$ & $74 \%$ & $0 \%$ & $26 \%$ \\
\hline \multicolumn{7}{|l|}{ FEAR OF FAT } \\
\hline $\begin{array}{l}\text { I feel disgusted with myself when } \\
\text { i gain weight. }\end{array}$ & $83 \%$ & $0 \%$ & $17 \%$ & $63 \%$ & $0 \%$ & $37 \%$ \\
\hline $\begin{array}{l}\text { One of the worst things that could } \\
\text { happen to me would be if I gained } \\
25 \text { pounds. }\end{array}$ & $6 \%$ & $2 \%$ & $82 \%$ & $3 \%$ & $5 \%$ & $92 \%$ \\
\hline I worry about becoming fat. & $35 \%$ & $30 \%$ & $35 \%$ & $37 \%$ & $13 \%$ & $50 \%$ \\
\hline \multicolumn{7}{|l|}{ WILLPOWER } \\
\hline $\begin{array}{l}\text { People who weigh too much } \\
\text { could lose at least some part } \\
\text { of their weight through a little } \\
\text { exercise. }\end{array}$ & $5 \%$ & $70 \%$ & $25 \%$ & $9 \%$ & $37 \%$ & $54 \%$ \\
\hline $\begin{array}{l}\text { Some people are fat because they } \\
\text { have no willpower. }\end{array}$ & $3 \%$ & $67 \%$ & $31 \%$ & $4 \%$ & $60 \%$ & $36 \%$ \\
\hline $\begin{array}{l}\text { Fat people tend to be fat pretty } \\
\text { much through their own fault. }\end{array}$ & $69 \%$ & $16 \%$ & $15 \%$ & $45 \%$ & $30 \%$ & $25 \%$ \\
\hline
\end{tabular}


lence of overweight and obesity has increased greatly worldwide, and in Serbia, according to the Ministry of Health, there were $20.2 \%$ overweight and $8.9 \%$ obese adolescents in 2013,which is a significant increase compared to 2000. Among our participants, $23 \%$ were overweight and obese, and these results are better than national data. Considering that it is known that obese people in adolescence most often remain obese throughout their lives, we believe that it is necessary to increase health education work in order to prevent obesity and other eating disorders. Having in mind that about one third of our participant had obese relatives, the explanation of our results may be in eating habits and engaging in the sports activity. Our students were asked to report if they are engaged in vigorous-intensity physical activity outside school hours, and 81\% stated "yes", which is in accordance with west Serbian data. Boys from the urban environment, with highly educated parents, are more engaged in the sports activity. Recent evidence suggests that having a high level of sedentary behavior has physiological and health implication [6].Our participants generally (77\%) stated sedentary behavior after school hours, but only $2 \%$ of them spent more than 3-4 hours watching TV and playing video games. This is very optimistic data, comparing with results from other countries, owing to the fact that our participants are medical students, aware of the potential benefits of regular sports activity. The dietary patterns of participants show great variability. Almost half of them had three meals per day, and two thirds of them 3-4. Students from the urban environment, with highly educated parents, stated they eat diverse and healthy meals. Only 3\% of them had less than three meals per day, so under nutrition is not the issue in west Serbia. Most of our participants $(81 \%)$ stated their meals were diverse. Previous studies have found that binge eating is the second prevalent eating disorder, particularly in youth who are overweight or obese $[7,8]$. Only $12 \%$ of our responders stated they never had binge eating, while others reported excessive eating every week, daily, or seldom. Binge eating has been linked to emotional stress, anxiety, mood disorders and low self-esteem, all frequently seen among adolescents [9].

In our study, participants were likely to choose carbonated sweet drinks regularly, in 64\%, especially in boys from the urban environment and from less-educated parents. Those beverages are very popular among adolescents worldwide, but are very dangerous due to their high energy density and potential impact on osteoporosis [10]. Regarding snacks, there are very limited targeted guidances for adolescents. Snacking was very common among our participant, and most of them $(88 \%)$ consumed sweets, slightly less in girls. Meal skipping rates may be highest during the adolescently period, with breakfast and dinner being the most frequently skipped meal (14-88\% and $4-57 \%$, respectively) [11]. Skipping breakfast was uncommon in our study. Only $8 \%$ of participants skipped breakfast, $43 \%$ had breakfast early in the morning, and 49\% later. Skipping dinner was also unusual (only 6\%) and only $7 \%$ of our participants had late dinner. This is a satisfying result because it is well known that skipping breakfast is common among adolescents, especially in girls. Late dinner can be potentially harmful considering obesity, as well as sleeping patterns. A study that explored dietary habits in Poland students showed that 25\% of students did not eat breakfast, $45,6 \%$ snacked in between main meals and $25 \%$ ate just before bedtime [12]. There are some commonalities in food preparation; in west Serbia, cooked meals are very common, and this could be the explanation why they were the most frequent choice in our survey. Meals cooked at home have a higher amount of essential nutrients and a lower amount of unhealthy ingredients [1]. Only $13 \%$ of our participants eat fried, and none of them deep-fried food. However, the contemporary dietary habits include some new food that today adolescents are very fond of, such as pizza, sandwiches and sweets. US adolescents over consumed fast food, which led to a high prevalence of obesity among them $[13,14]$. During lunch time, the majority of our participants, usually from less-educated parents, consumed unhealthy food from the bakery, which is typical for West Balcan. $44 \%$ of the participants reported consumption of sweets regularly, on daily basis, $23 \%$ with a frequency of 2-3 times per week, and only $3 \%$ consumed no sweets. Sweets were heavily consumed in our study, comparing with another study [15]. We see that as a problem, because, sweets are tasteful, but with high energy density, and a lot of negative health outcomes. On the other hand, restricting access to tasteful foods, whether self-imposed or by parental control, may have potentially negative consequences [16]. Having a fear of getting fat is an important question, because adolescents may be mainly sensitive to their weight and body im- 
aging, which may lead to risky behaviors [13]. Only $22 \%$ of our participants stated the fear of getting fat, but $73 \%$ never had a restrictive diet, compared to $40,8 \%$ of participants in a study of Napolitano et al. [17]. Different results were obtained in studies from France, Spain, and Portugal [18-20].

Among adolescents who were on a restrictive diet in our study, the waist majority conducted diet recommended by the Internet or friends' instructions. School, parents and the Internet equally influenced the knowledge about healthy nutrition among our participants. Considering that almost all of our participants had access to the Internet and television, it is important that advertisements on those media contain professional advice regarding healthy nutrition. Questions regarding the need for additional education about nutrition revealed that $85 \%$ of participants felt like they needed more information about healthy nutrition; thus, again, media, school and parents are important players in this part of their kid's education.

Nowadays societies highly stigmatize obesity, leading to negative attitudes and behavior toward obese individuals [21,22]. Moreover, overweight and obese adolescents face an increased likelihood of being socially marginalized by their peers. They are less popular, and additionally, there are beliefs that weight is controllable, and that fat people have their own responsibility about weight. In our study, participants declared their fear of being fat and put additional weight on, but they did not blame fat people for being fat, and did not think that obesity is attributable to a lack of willpower and personal responsibility. A gender difference was found for explicit antifat attitudes, with females reporting more dislike of fat people, which is different from one study [23] but in accordance with others [21,22]. It is obvious from our results that females displayed more dislike attitudes towards fat people than boys did. While many adolescent girls desire to be thinner, boys desire to be more corpulent, and this may be the explanation for the results of our study. No one in our study stated dislike of fat people, or any doubt about their intelligence and reliability. Generally, they revealed tolerance, no prejudice and a non judgmental attitude. This is important because weight discrimination is prevalent, particularly in American society and among women [24]. But, as it was shown in a study from O'Brien, commonly used measures of antifat attitudes do not appear to be adequate predictors of antifat discrimination, so we urge for more research and antifat discrimination measures [23].

\section{CONCLUSION}

A healthy diet and the right attitudes of young people regarding this topic are important aspects of the health of the adolescent population. Numerous cultural, economic and social factors affect health. The health potential related to nutrition is influenced by the health literacy and quality of life of adolescents. Years of transition brought some improper eating habits among adolescents in west Serbia, so more education are needed to sustain a healthy lifestyle.

\section{ETHICS DECLARATIONS}

Conflict of interest

The authors declare that they have no conflict of interest, the research respects ethical norms and principles. 


\section{REFERENCES}

1. Carmody R, Wrangham R. The energetic significance of cooking. Journal of Human Evolution. 2009;57(4):379-391.

2. Cole T, Flegal K, Nicholls D. Body mass index cut offs to define thinness in children and adolescents: international survey. BMJ. 2007;335(7612):194.

3. Crandall C. Prejudice against fat people: Ideology and self-interest. Journal of Personality and Social Psychology. 2020;66(5):882-894.

4. UNICEF. The State of the World's Children 2019. Children, Food and Nutrition: 2019. 112-152.

5. Spinelli A, Buoncristiano M, Kovacs V et al. Prevalence of Severe Obesity among Primary School Children in 21 European Countries. Obesity Facts. 2019;12(2):244-258.

6. Tremblay M, Colley R, Saunders T. Physiological and health implications of a sedentary lifestyle. Applied Physiology, Nutrition, and Metabolism. 2010;35(6):725-740.

7. Keski-Rahkonen A, Mustelin L. Epidemiology of eating disorders in Europe. Current Opinion in Psychiatry. 2016;29(6):340-345.

8. Ministarstvo zdravlja Republike Srbije. Strategija javnog zdravlja u Republici Srbiji. Službeni glasnik RS 2018:61.

9. Goldschmidt A, Lavender J, Hipwell A. Examining Two Prevailing Models of Loss of Control Eating Among Community-Based Girls. Obesity. 2017;26(2):420-425.

10. Woodward-Lopez G, Kao J, Ritchie L. To what extent have sweetened beverages contributed to the obesity epidemic?. Public Health Nutrition. 2010;14(03):499-509.

11. Pendergast F, Livingstone K, Worsley A. Correlates of meal skipping in young adults: a systematic review. International Journal of Behavioral Nutrition and Physical Activity. 2016;13(1).

12. AP L. Nutrition and Long-Term Cardiovascular Health. Journal of Food and Nutritional Health. 2020;1(1).

13. Liechty J, Lee M. Longitudinal predictors of dieting and disordered eating among young adults in the U.S. International Journal of Eating Disorders. 2013;46(8):790-800.

14. Veronese N, Stubbs B, Noale M et al. Fried potato consumption is associated with elevated mortality: an 8-y longitudinal cohort study. The American Journal of Clinical Nutrition. 2017;106(1):162-167.

15. Eleni Evagelou, Eugenia Vlachou, Maria Polikandrioti et al. Exploration of Nursing students' dietary habits. Health Science Journal 2014:8:4-6

16. Manning L, Soon J. Food Safety, Food Fraud, and Food Defense: A Fast Evolving Literature. Journal of Food Science. 2016;81(4):R823-R834.

17. Bencivenga F, Pompili E, Angelillo I. Assessment of Knowledge, Attitudes, and Behaviors toward Eating Disorders among Adolescents in Italy. International Journal of Environmental Research and Public Health. 2019;16(8):1448.

18. López-Guimerà G, Neumark-Sztainer D, Hannan P. Unhealthy Weight-control Behaviours, Dieting and Weight Status: A Cross-cultural Comparison between North American and Spanish Adolescents. European Eating Disorders Review. 2012;21(4):276-283.

19. Sarafrazi N, Hughes JP, Borrud L, Burt V, Paulose-Ram R. Perception of weight status in U.S. children and adolescents aged 8-15 years, 2005-2012. NCHS Data Brief. 2014 Jul;(158):1-7.

20. Deschamps V, Salanave B, Chan-Chee C. Body-weight perception and related preoccupations in a large national sample of adolescents. Pediatric Obesity. 2014;10(1):15-22.

21. Di Pasquale R, Celsi L. Stigmatization of Overweight and Obese Peers among Children. Frontiers in Psychology. $2017 ; 8$.

22. Hinman N, Burmeister J, Kiefner A. Stereotypical portrayals of obesity and the expression of implicit weight bias. Body Image. 2015;12:32-35.

23. O'Brien K, Latner J, Halberstadt J. Do Antifat Attitudes Predict Antifat Behaviors?. Obesity. 2008;16(S2):S87-S92.

24. Puhl R, Andreyeva T, Brownell K. Perceptions of weight discrimination: prevalence and comparison to race and gender discrimination in America. International Journal of Obesity. 2008;32(6):992-1000. 